\title{
Copper Nanoparticles as Potential Antimicrobial Agent in Disinfecting Root Canals. A Systematic Review.
}

\author{
Nanopartículas de Cobre como Potencial Agente Antimicrobiano en la \\ Desinfección de Canales Radiculares. Revisión Sistemática
}

\author{
Sánchez-Sanhueza Gabriela*; Fuentes-Rodríguez Daniela** \& Bello-Toledo Helia***
}

SÁNCHEZ-SANHUEZA, G.; FUENTES-RODRÍGUEZ, D. \& BELLO-TOLEDO, H. Copper nanoparticles as potential antimicrobial agent in disinfecting root canals. A systematic Review. Int. J. Odontostomat., 10(3):547-554, 2016.

ABSTRACT: Copper was registered as the first solid antimicrobial material. Its availability makes it an important option as an antibacterial agent. At nanoparticle size it does not exceed $100 \mathrm{~nm}$, allowing close interaction with microbial membranes, enhancing its effect even more. Copper generates toxic hydroxyl radicals that damage cell membranes of Gram-negative and Gram-positive bacteria, among the latter, Enterococcus faecalis, which are present in infected radicular canals. Synthesis of metal nanoparticles with antimicrobial properties has become a viable alternative and has promising applications in the fight against pathogenic microorganisms. Furthermore, the use of some polymers to stabilize nanoparticles increases their release time and may as well decrease the risk of bacterial recolonization and biofilm formation within the ducts, enhancing the antimicrobial properties of these compounds. The aim of this article is to conduct a systematic review of the literature on antimicrobial copper nanoparticles, their current applications and their potential use in the area of oral health, specifically in the field of endodontics.

KEY WORDS: copper nanoparticles, antibacterial, endodontics.

\section{INTRODUCTION}

Copper is an essential element for the metabolism of animal and plant cells. It is a trace element present in most organisms, and there are more than 30 types of proteins that contain it. Copper, along with gold, were the first metals used by man more than 9000 years ago. Today copper consumption worldwide is about 18 million tons per year.

Its antimicrobial activity is recognized worldwide and has recently been registered by the US Environmental Protection Agency as the first solid antimicrobial material. As early as 2200 B.C. it was used to sterilize wounds and drinking water. In the nineteenth century it was observed that copper workers were immune to cholera, and its use became widespread in the twentieth century.
Laboratory and clinical studies have been conducted to demonstrate its effectiveness. In recent years, copper has been used as a building material for hospitals and medical centers as its antimicrobial properties proved useful in the fight against infections. These findings are particularly important for Chile, the main copper producer in the world (Prado et al., 2012). The synthesis or extraction of compounds such as nanoparticles with antimicrobial properties is important and has potentially promising applications in the fight against the increasing number of pathogens resistant to currently available antimicrobials. These pathogens pose a continuous threat to human and animal health (Usman et al., 2013 \& Kruk et al., 2015).

This paper presents a systematic review of the literature on antimicrobial copper nanoparticles, their

\footnotetext{
Assistant Professor. Discipline of Endodontics. Department of Restorative Dentistry, Faculty of Dentistry, Universidad de Concepción, Concepción, Chile.

* Undergraduate Student, Faculty of Dentistry, Universidad de Concepción, Concepción, Chile.

*** Associate Professor. Research Laboratory of Antibacterial Agents, Department of Microbiology, Faculty of Biological Sciences, Universidad de Concepción, Concepción, Chile.
} 
current applications and their potential use in the area of oral health, specifically in the field of endodontics.

\section{MATERIAL AND METHOD}

Eligibility criteria: Original papers from all levels of evidence according to the classification of the Oxford Centre for Evidence-Based Medicine (http:// www.cebm.net/ocebm-levels-of-evidence) published between 2005 and 2015 (including both years). The most important journals in English and Spanish were included in this review. These papers should contain data about the use of antimicrobial copper nanoparticles and their applications in the area of health care. The period reviewed allowed an assessment of the topic that included research and publications supported by recent findings. The exclusion of non-on line publications was based on the need of conducting a systematic and replicable review.

Sources: Considering the main databases and languages of important journals in biomedical sciences, especially dentistry, the following databases were used: MEDLINE, EMBASE, LILACS, SciELO, Science Direct, IBECS, Cochrane and CENTRAL. Search engines LILACS and EMBASE were used, as they give access to all the above mentioned databases. The search was conducted between April and June 2015.

Search: The preliminary search algorithm used in EMBASE was the following: (nanoparticles*ab,ti OR

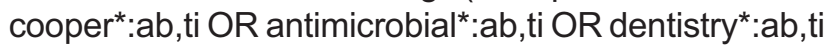
OR endodontics *:ab,ti) AND [2005-2015]/py. In LILACS: tw (nanoparticles* OR cooper* OR antimicrobial* $^{*}$ OR dentistry* OR endodontics*) and year_cluster (2005-2015). The search was refined in successive iterations to consider the inclusion and/or modification of key words found in papers during previous iterations. The algorithm was considered completed when new modifications and/or inclusions gave different results from the previous iteration.

Study selection: From the results in search engines EMBASE and LILACS, the first filtering was performed according to the title of the papers; the second, by the abstract and finally by the full-text. The full application of the inclusion and exclusion criteria described above was considered in the review of the full text. The selected papers were finally classified and registered on an electronic spreadsheet (MS Excel, Microsoft Corp., USA) with their respective bibliographic information.

\section{RESULTS}

Fifty-one articles were selected by the search methodology. Nine corresponded to literature reviews and forty-one to experimental studies. Only four of them were related to dental literature containing data about research on copper nanoparticles. Evidence shows that there is preliminary emerging research regarding the use of nanoparticles of copper in dentistry, especially in endodontic. Regarding its antimicrobial properties and its use in the field of human health, some studies support its application as an alternative to treat multiresistant bacteria.

\section{DISCUSSION}

Copper as Antibacterial. Copper has bactericidal action, mainly related to its ability to give and accept electrons in a continuous process. It produces a hydroxyl radical that can participate in a number of adverse reactions to cellular macromolecules such as protein and lipid oxidation. The generated hydrogen peroxide can lead to increased production of toxic hydroxyl radicals. It causes displacement of iron from iron-sulfur clusters, it can compete with zinc or other metal ions, important in protein binding sites; it destroys the membrane, denatures DNA and blocks cellular respiration. In turn bacteria developed tolerance mechanisms to copper such as the extracellular sequestering of ion, impermeability of the outer and inner bacterial membranes, removing copper proteins (metallothionein) in the cytoplasm and periplasm, and efflux of copper from cell (Grass et al., 2011).

Copper alloys acting on abiotic surfaces showed that besides the rapid death of antibiotic resistant strains, it caused destruction of plasmid and genomic DNA, which has an implication in preventing the spread of infections and gene transfer (Warnes et al., 2013 \& Bagchi et al., 2013). Copper surfaces or their alloys are able to eliminate $99.9 \%$ of pathogenic bacteria in hours, including methicillin-resistant Staphylococcus aureus (MRSA), Escherichia coli, Pseudomonas aeruginosa, Listeria monocytogenes, Salmonella enterica, Campylobacter jejuni, Legionella pneumophila, Clostridium difficile and Mycobacterium tuberculosis. Exposing bacteria to copper surfaces makes the cells undergo extensive membrane damage within minutes. The sharp contact with metallic copper surfaces did not result in an increase in mutation rates 
or bacterial DNA lesions (Santo et al., 2011). The starting point for the clinical use of copper, specifically for disinfecting the root canal system is reported in a ex vivo study where the canals treated with copper sulfate pentahydrate showed a reduction of 6 logarithms in the count of colony-forming units on the fourth day (Sánchez-Sanhueza et al., 2015).

Antibacterial Nanoparticles. Nanoparticles are particles with a size not greater than $100 \mathrm{~nm}$, with spherical, cubic and needle-shaped forms (5-100 nanometers to micrometers) (Allakeret et al., 2014). They are formed from different materials, either metallic or polymeric and their active surface area, chemical reactivity and biological activity, are often radically different from larger size particles. These features allow the nanoparticles interact closely with microbial membranes and, therefore, their antimicrobial effect is not due exclusively to the release of metal ions (Morones et al., 2005). Nanoparticles are potentially useful in this context, since it is possible to alter their surface charge, hydrophobicity, and other physical and chemical characteristics. This information is important for the safe use of nanomaterials (Nel et al., 2009).

An inverse relationship between the size of the nanoparticles and antimicrobial activity has been clearly demonstrated, where particles in the range of 1-10 nm in size have demonstrated greater killing activity against bacteria compared to larger particles. It is reported that in Gram-negative bacteria nanoparticles acted mainly in the range of $1-10 \mathrm{~nm}$. In addition, by adhering to the surface of the cell membrane, they drastically disrupt its functions, such as permeability and cellular respiration. They are able to penetrate into the bacteria and cause further damage by possible interactions with sulfur and phosphorus-containing compounds such as DNA. They release ions, which will make an additional contribution to the bactericidal effect of nanoparticles. However, in the case of silver nanoparticles, it has been shown that smaller nanoparticles are more toxic than larger particles, even when they are oxidized (Lok et al., 2007).

The shape of the nanostructure can also affect the activity of the nanoparticles, as demonstrated against Escherichia coli. Silver triangular nanoplates truncated with a plane $(1,1,1)$ showed better biocidal activity than spherical and rod-shaped nanoparticles. The differences appear to be explained by the proportion of active facets in nanoparticles with different forms (Pal et al., 2007).
It is suggested that bacteria are much less likely to develop resistance to metal nanoparticles in comparison to conventional antibiotics. This is because metals can act on a wide range of microbial targets, and many mutations would have to occur for the microorganisms to resist their antimicrobial activity. Metals have been used for centuries as antimicrobial agents. Silver, copper, gold, titanium, zinc have gained particular attention, each having different properties and spectra of action (Allaker, 2010).

With respect to nanoparticles, the antimicrobial properties of silver and copper have received the most attention. Both have been incorporated into various materials including polymethylmethacrylate (PMMA) and hydrogels.

Bacterial susceptibility to nanoparticles depends on several factors such as the bacterial strain, the type and size of nanoparticles, the nature of the initial growth media and cell concentration. In general, Gramnegative organisms are more resistant to the ion effect of copper nanoparticles than Gram-positive bacteria (Yang et al., 2015).

There is growing interest in the application of nanoparticles as oral antimicrobials to control various infections, for their biocidal properties and anti-adhesive capabilities against biofilms. In dentistry there are some studies reporting the use of antimicrobial nanoparticles as components of prosthetic coatings, and topical agents within dental materials, but there are still very few reports about their use as medication in endodontics (Kishen, 2010). Bacteria isolated from root canals can be set in intracanal biofilms in the dentinal tubules of 1-5 microns in diameter, and the uptake and penetration of antimicrobial agents in them are key considerations in therapeutic results.

Copper Nanoparticles. In the form of nanoparticles, the antimicrobial properties of copper are among the most described (Ren et al., 2009). Compared to traditional antibiotics, nanoparticles are effective at concentrations 1000 times lower. Periodontal pathogens like Porphyromonas gingivalis, Fusobacterium nucleatum, Prevotella intermedia and Aggregatibacter actinomycetemcomitans were found to be susceptible to silver nanoparticles and copper oxide $(\mathrm{CuO})$ in anaerobic conditions, with minimum bactericidal concentrations (MBC) ranging from 0.025 to $2.5 \mathrm{mg} / \mathrm{ml}$ (Prado et al., 2012). However, copper is cheaper than silver, readily miscible with polymers, and relatively stable chemically and physically. 
$\mathrm{CuO}$ is a compound semiconductor with a monoclinic structure and is the simplest member of the family of copper compounds. It has a range of useful properties such as high temperature superconductivity, correlation effects of electron and dynamic rotation. While copper may have a similar mode of action to silver, it is believed that the key is the action of copper in $\mathrm{SH}$-groups of microbial enzymes. It has been shown that copper nanoparticles have higher affinity to amines and carboxyl groups in a high density on the surface of Bacillus subtilis than silver nanoparticles, resulting in a higher antimicrobial activity. Another report reinforces the finding that copper acts better on $\mathrm{B}$. subtilis when compared to silver nanoparticles (Yoon et al., 2007), but not on S. aureus and E. coli (Ruparelia et al., 2008). CuO nanoparticles in suspension show activity against a variety of bacterial pathogens including MRSA and E. coli, with minimum inhibitory concentrations (MIC) ranging from $0.1 \mathrm{mg} / \mathrm{ml}$ to 5.0 $\mathrm{mg} / \mathrm{ml}$. Copper oxide (I) or cuprous oxide (Cu2O) is a red powder and can also be produced as nanoparticles, which has shown activity against a range of species and strains of bacteria.

Regarding biosafety, one study compared the toxicity and accumulation of two different copper compounds, $\mathrm{CuO}$ nanoparticlesand soluble CuSO4, in erythrocytes and different tissues in rainbow trout (Oncorhynchus mykiss). The results of in vitro toxicity indicate that both copper compounds increase the rate of hemolysis in a dose-dependent manner, but the effect is lowerwhen cells are treated with $\mathrm{CuO}$ nanoparticles. Furthermore, both copper compounds cause DNA damage, which was more pronounced in cells treated with CuSO4. Copper concentrations in kidney and gill were significantly higher in fish exposed to CuSO4 compared with $\mathrm{CuO}$ nanoparticles. Significant DNA damage was detected only when $\mathrm{Cu}$ was injected as CuSO4 in comparison to controls. These data suggest that $\mathrm{Cu}$ nanoparticles are less toxic than at their macroscale size (Isani et al., 2013). Another report noted that copper toxicity to A6 cells of a frog (Xenopus laevis) depends on the form of copper and the state of the cell, so that the effects were produced before stages of differentiation and proliferation. The three forms of copper tested, (Cu2+; $\mathrm{CuO}$ nanoparticles $(6 \mathrm{~nm})$ and $\mathrm{CuO}$ nanoparticles polydisperse (poly-CuO) caused an increase of cell death and altered cell cycle progression, being poly$\mathrm{CuO}$ the one that caused the most serious effects. It may be considered that the poly-CuO particles were highly polydisperse, with sizes ranging from 40 to 500 $\mathrm{nm}$ in deionized water, with a majority measuring around $100 \mathrm{~nm}$, and therefore containing particles, both within and outside the defined nano scale (Thit et al., 2013). To test the consequences of the exposure of brain cells to $\mathrm{CuO}$ nanoparticles, with a diameter of about $5 \mathrm{~nm}$, cultures of primary brain astrocytes were exposed to $\mathrm{CuO}$ nanoparticles, where increased levels of intracellular copper were observed, affecting the cell viability which depends on concentration and temperature. Their application in concentrations above $100 \mathrm{mM}$ copper $(6.4 \mathrm{~g} / \mathrm{ml})$ severely compromised the viability of cells. Induced toxicity by $\mathrm{CuO}$ nanoparticles was accompanied by an increase in the generation of reactive oxygen species (ROS) into cells (Bulcke et al., 2014). Conventional physical and chemical methods of synthesizing metal nanoparticles may be one of the possible reasons for their toxicity. This problem may be overcome by synthetizing nanoparticles from biological sources.

The method of chemical reduction appears to be the most versatile for producing metal nanoparticles because it is simple and inexpensive. It usually involves the reduction of metal salts with a reducing agent in any type of solvent and a capping agent to keep growth of a nanoparticle at specific and required size. One of the most challenging aspects of the synthesis of copper nanoparticles is their high tendency to oxidation (Zain et al., 2014).

Copper nanoparticles have important limitations, including the rapid oxidation in air exposure. Copper is oxidized to $\mathrm{CuO}$ and $\mathrm{Cu} 2 \mathrm{O}$, and becomes $\mathrm{Cu} 2+$ during preparation and storage, so it is difficult to synthesize copper nanoparticles in a natural environment. Moreover, an excess of copper in the human body leads to the generation of the most detrimental radicals, such as the hydroxyl radical. However, there are enzymes such as copper triphosphatases adenosine (CuATPases), which play an important role in the homeostasis of copper, and the excess is export through the intestine as feces, through the liver as a product of bile, and through the breast gland in the milk.

It is known that bacteria have strict control over the transport of copper (Input-Output), ensuring the homeostasis required for protein synthesis and prevention of toxic effects, by a highly controlled system of transcriptional regulators, soluble chaperone, membrane transporters, and cooper proteins distributed in various bacterial compartments (Rademacher et al., 2012; Elguindi et al., 2011). Most bacteria synthesize P-type ATPase export of copper 
as main determinants of defense when copper concentrations are higher than average. In addition, many bacteria use the efflux systems RND and multicopper oxidases to deal with excess copper (Shrestha et al., 2014).

An attempt to establish metal nanoparticles with physiological importance as the best candidates for future nanomedicine can only succeed if these particles are synthesized with improved biocompatibility and low or no toxicity (Sengupta et al., 2014). Today we talk of "Green Nanotechnology" and "nanotoxicology" as two important areas of research on nanomaterials. A report showed that colloids of silver nanoparticles supported on biopolymers, stabilize nanoscale particles, making them minimally toxic and maintaining their antimicrobial activity, which has profound biomedical implications (Barua et al., 2013). Cu2O nanoparticles were prepared, using agricultural waste Arachis hypogaea (peanuts), leaf extracts containing reducing sugars, which act as reducing agent at room temperature (Ramesh et al., 2011). The aldehyde group present in reducing sugar plays an important role in the formation of cuprous oxide nanoparticles in the solution. Another report notes that morphology of $15-30 \mathrm{~nm}$ copper oxide nanoparticles can be controlled by regulating the amount of Aloe vera extract. This ecological approach for synthesis is suitable for commercial scale production and related health $\mathrm{CuO}$ nanoparticles applications (Gunalan et al., 2012; Kharissova et al., 2013.).

Other alternatives developed to synthesize metal nanoparticles are the use of polymers, for example polyvinylpyrrolidone, polyethylene glycol, and chitosan. Nanoparticles stabilized by biopolymers prolong their release time, which improves, among other things, their antimicrobial properties. Chitosan is the second most abundant biopolymer of natural origin after cellulose and is obtained by removing an acetyl group from chitin. It consists of glucosamine units and $\mathrm{N}$ acetylglucosamine. It is a biocompatible, biodegradable, nontoxic polymer, and has various applications in pharmaceutical and biomedical fields. It presents positive charge and is soluble in acidic to neutral solution, allowing it to bind to mucosal surfaces. These properties make chitosan a good candidate for medical applications and research (Sani-Usman et al., 2012).

Chitosan-copper nanoparticle surfaces are covered by fragments of chitosan that protect against aggregation and oxidation, increasing the release time of the compound. It was shown that the size of nanoparticles could be controlled by manipulating the concentrations of chitosan and silver, and copper nitrate used in their synthesis. Particle size could be increased either by decreasing the concentration of chitosan or increasing the concentration of metal ions. Nanoparticles produced had a positive surface charge and chitosan used in their synthesis contributed to the stability of suspensions of such particles and had a bactericidal effect (Mallick et al., 2012).

Although antimicrobial irrigants (without incorporation of chitosan) currently used to disinfect root canals in treating endodontic infections are able to kill Enterococcus faecalis, they often fail in endodontic restorations. An in vitro study by Kishen et al. (2008) showed that the root canal surfaces treated with cationic antibacterial nanoparticles combined with chitosan significantly reduced the adhesion of $\mathrm{E}$. faecalis to dentin. In theory, such surface treatment may prevent bacterial recolonization and biofilm formation.

One research established a starting point for the potential clinical use of copper in endodontics. In this study the drugs commonly used in endodontics and copper sulfate pentahydrate were compared. It was observed that copper sulfate presented an antimicrobial activity superior to concentrations lower than Chlorhexidine (Sierra et al., 2013). Therefore, the antibacterial properties of copper at nanoscale could also have applications in endodontics, since the environment in the root canal, which serves as ecological niche for microorganisms, is a surface made up of small dentinal tubules composed of collagen and hydroxyapatite; and they are established in the form of biofilm, and as copper is considered a contact antibacterial, its usage time could be reduced to the minimum necessary (Kim et al., 2013; Reyes-Jara et al., 2010).

\section{CONCLUSION}

Copper nanoparticles are a group of toxic antimicrobials for the cell membrane of Gram-negative and Gram-positive bacteria, so it could be a therapeutic alternative in the future, either as intracanal medication or as an irrigant to decontaminate and disinfect the root canal. Moreover, this compound may be enhanced with polymers as chitosan, which stabilizes these nanoparticles, increasing their biocompatibility, release time, reducing the risk of bacterial recolonization and 
biofilm formation within the ducts, enhancing its antimicrobial properties. Although more research on the effectiveness of copper nanoparticles in disinfecting root canals is required, the antimicrobial potential of this metal, together with its high availability and low cost, make it worthy of consideration as a therapeutic alternative for successful future root treatments.

\section{ACKNOWLEDGEMENTS}

The researchers would like to thank grants (CONICYT-PCHA / DoctoradoNacional / 2013 folio 21130022), for PhD in Science, Major in Microbiology, Universidad de Concepcion, for their support.

SÁNCHEZ-SANHUEZA, G.; FUENTES-RODRÍGUEZ, D. \& BELLO-TOLEDO, H. Nanopartículas de cobre como potencial agente antimicrobiano en la desinfección de canales radiculares. Revisión sistemática. Int. J. Odontostomat., 10(3):547-554, 2016.

RESUMEN: El cobre fue registrado como el primer material antimicrobiano sólido y su disponibilidad permite que constituya una importante opción como agente antibacteriano. Al tamaño de nanopartícula no supera los $100 \mathrm{~nm}$, lo que permite una interacción estrecha con las membranas microbianas, potenciando aún más su efecto. Genera radicales hidroxilos tóxicos que provocan daño en la membrana celular de bacterias Gram negativas y Gram positivas, entre estas últimas, Enterococcus faecalis, presente en conductos radiculares infectados. Por lo que la síntesis de nanopartículas metálicas con propiedades antimicrobianas se ha vuelto una alternativa viable con aplicaciones prometedoras en la lucha contra microorganismos patógenos. Además, utilizando algunos polímeros para estabilizar las nanopartículas se aumenta el tiempo de liberación de éstas y se disminuye el riesgo de recolonización bacteriana y la formación de biopelículas al interior de los conductos, mejorando las propiedades antimicrobianas de estos compuestos. El propósito de este artículo es realizar una revisión sistemática de la literatura acerca de nanopartículas de cobre como antimicrobiano, sus aplicaciones actuales y su potencial uso en el área de la salud oral, específicamente en el campo de la Endodoncia.

PALABRAS CLAVES: nanopartículas de cobre, antibacteriano, endodoncia.

\section{REFERENCES}

Ahmad, Z.; Vargas-Reus, M.; Bakhshi, R.; Ryan, F.; Ren, G.
\& Oktar, F. Antimicrobial Properties of Electrically Formed Elastomeric Polyurethane-Copper Oxide Nanocomposites for Medical and Dental Applications. Methods. Enzymol., 509:87-99, 2012.

Allaker, R. \& Memarzadeh, K. Nanoparticles and the control of oral infections. Int. J. Antimicrob. Agents., 43(2):95-104, 2014.

Allaker, R. The Use of Nanoparticles to Control Oral Biofilm Formation. J. Dent. Re., 89(11):1175-86, 2010.

Azam, A.; Ahmed, A.; Oves, M.; Khan, M. \& Memic, A. Sizedependent antimicrobial properties of $\mathrm{CuO}$ nanoparticles against Gram-positive and -negative bacterial strains. Int. J. Nanomedicine., 7:3527-35, 2012.

Bagchi, B.; Kar, S.; Dey, S.; Bhandary, S.; Roy, D. \& Mukhopadhyay, T. In situ synthesis and antibacterial activity of copper nanoparticle loaded natural montmorillonite clay based on contact inhibition and ion release. Colloids Surf. B. Biointerfaces., 108:35865, 2013.

Barua, S.; Konwarh, R.; Bhattacharya, S. Non-hazardous anticancerous and antibacterial colloidal 'green'silver nanoparticles. Colloids Surf. B. Biointerfaces., 105:3742, 2013.

Bashir, O.; Hussain, S.; AL-Thabaiti, S. \& Khan, Z. Synthesis, optical properties, stability, and encapsulation of Cu-nanoparticles. Spectrochim. Acta A Mol. Biomol. Spectrosc., 140:265-73, 2015.

Bulcke, F.; Thiel, K. \& Dringen, R. Uptake and toxicity of copper oxide nanoparticles in cultured primary brain astrocytes. Nanotoxicology., 8(7):775-85, 2014.

Carpio-Perochena, A.; Kishen, A.; Shrestha, A. \& Monteiro, C. Antibacterial Properties Associated with Chitosan Nanoparticle Treatment on Root Dentin and 2 Types of Endodontic Sealers. J. Endod., 41(8):1353-8, 2015.

Chatterjee, A.; Chakraborty, R. \& Basu, T. Mechanism of antibacterial activity of copper nanoparticles. Nanotechnology., 25(13):135101, 2014.

Civardi, C.; Schwarze, F. \& Wick, P. Micronized copper wood preservatives: An efficiency and potential health risk assessment for copper-based nanoparticles. Environ. Pollut., 200:126-32, 2015.

Elguindi, J.; Moffitt, S.; Hasman, H.; Andrade, C.; Raghavan, S. \& Rensing, C. Metallic copper corrosion rates, moisture content, and growth medium influence survival of copper ion-resistant bacteria. Appl. Microbiol. Biotechnol., 89:1963-70, 2011. 
Grass, G.; Rensing, C. \& Solioz, M. Metallic copper as an antimicrobial surface. Appl. Environ. Microbiol., 77:1541-47, 2011.

Gunalan, S.; Sivaraj, R. \& Venckatesh, R. Aloe barbadensis Miller mediated green synthesis of mono-disperse copper oxide nanoparticles: Optical properties. Spectrochim. Acta A Mol. Biomol. Spectrosc., 97:114044, 2012.

Isani, G.; Falcioni, M. \& Barucca, G. Comparative toxicity of $\mathrm{CuO}$ nanoparticles and $\mathrm{CuSO}<\mathrm{sub}>4$ in rainbow trout. Ecotoxicol. Environ. Saf., 97:40-6, 2013.

Karlsson, H.; Cronholm, P.; Hedberg, Y.; Tornberg, M.; De Battice, L. \& Svedhem, S. Cell membrane damage and protein interaction induced by copper containing nanoparticles-Importance of the metal release process. Toxicology., 313(1):59-69, 2013.

Kharissova, O.; Dias, H.; Kharisov, B.; Pérez, B. \& Pérez, V. The greener synthesis of nanoparticles. Trends. Biotechnol., 31(4):240-8, 2013.

Khodashenas, B. \& Ghorbani, H. Synthesis of copper nanoparticles: An overview of the various methods. Korean J. Chem. Eng., 31(7):1105-9, 2014.

Kim, S.; Shin, Y.; Lee, C. \& Jung, I. In vivo quantitative evaluation of live and dead bacteria in root canal infection by using propidiummonoazide with real-time PCR. J. Endod., 39(11):1359-63, 2013.

Kishen, A. Advanced therapeutic options for endodontic biofilms. Endod. Topics., 22(1):99-123, 2010.

Kruk, T.; Szczepanowicz, K.; Stefanska, J.; Socha, R. \& Warszynski, P. Synthesis and antimicrobial activity of mono disperse copper nanoparticles. Colloids Surf. B. Biointerfaces., 128:17-22, 2015.

Lok, C.; Ho, C. \& Chen, R. Silver nanoparticles: partial oxidation and antibacterial activities. J. Biol. Inorg. Chem., 12:527-34, 2007.

Mallick, S.; Sharma, S.; Banerjee, M.; Ghosh, S.; Chattopadhyay, A. \& Paul, A. lodine-Stabilized Cu Nanoparticle Chitosan Composite for Antibacterial Applications. ACS Appl. Mater. Interfaces., 4(3):131323, 2012

Modaresi, J.; Baharizade, M.; Shareghi, A.; Ahmadi, M. \& Daneshkazemi, A. Copper Ion as a New Leakage Tracer. J. Dent. (Shiraz)., 14(4):155-9, 2013.

Morones, J.; Elechiguerra, J. \& Camacho, A. The bactericidal effect of silver nanoparticles. Nanotechnology., 16:2346-53, 2005.
Neelakantan, P.; Sanjeev, K. \& Subbarao, C.V. Durationdependent susceptibility of endodontic pathogens to calcium hydroxide and chlorhexidene gel used as intracanal medicament: an in vitro evaluation. Oral Surg. Oral Med. Oral Pathol. Oral Radiol. Endod., 104(4):e13841, 2007.

Nel, A.E.; Madler, L. \& Velegol, D. Understanding biophysicochemical interactions at the nano-bio interface. Nat. Mater., 8:543-57, 2009.

Pal, S.; Tak, Y.K. \& Song, J.M. Does the antibacterial activity of silver nanoparticles depend on the shape of the nanoparticle? A study of the Gram-negative bacterium Escherichia coli. Appl. Environ. Microbiol., 73(6):171220, 2007.

Palza, H. Antimicrobial Polymers with Metal Nanoparticles.Int. J. Mol. Sci., 16:2099-116, 2015.

Prado, J.V.; Vidal, A.R. \& Durán, T.C. Application of copper bactericidal properties in medical practice. Rev. Med. Chil., 140(10):1325-32, 2012

Rademacher, C. \& Masepohl, B. Copper-responsive gene regulation in bacteria. Microbiology., 158:2451-64, 2012.

Ramesh, C.; HariPrasad, M. \& Ragunathan, V. Effect of Arachishypogaea L. leaf extract on barfoed's solution; green synthesis of $\mathrm{Cu} 2 \mathrm{O}$ nanoparticles and its antibacterial effect. Current Nanoscience., 7:995-9, 2011.

Ren, G.; Hu, D.; Cheng, E.W.; Vargas-Reus, M.A.; Reip, P. \& Allaker, R.P. Characterisation of copper oxide nanoparticles for antimicrobial applications. Int. J. Antimicrob. Agents., 33(6):587-90, 2009.

Reyes-Jara, A.; Latorre, M. \& Lopez, G. Genome-wide transcriptome analysis of the adaptive response of Enterococcus faecalis to copper exposure. Biometals., 23:1105-12, 2010.

Rittapai, A.; Urapepon, S.; Kajornchaiyakul, J. \& Harniratisai, C. Properties of experimental copper-aluminium nickel alloys for dental post-and-core applications. J. Adv. Prosthodont., 6(3):215-23, 2014.

Ruparelia, J.; Chatterjee, A.; Duttagupta, S. \& Mukherji, S. Strain specificity in antimicrobial activity of silver and copper nanoparticles. Acta Biomater., 4(3):707-16, 2008.

Sánchez-Sanhueza, G.; Alcántara-Dufeu, R.; Carrillo, L.; Mansilla, H.; Novoa, C.\& Bello-Toledo, H. Ex vivo effect of copper sulfate on Enterococcus faecalis in root canal. Int. J. Odontostomat., 9(3):505-10, 2015.

Sani-Usman, M.; Ibrahim, N.; Shameli, K.; Zainuddin, N. \& Yunus, W. Copper Nanoparticles Mediated by Chitosan: 
SÁNCHEZ-SANHUEZA, G.; FUENTES-RODRÍGUEZ, D. \& BELLO-TOLEDO, H. Copper nanoparticles as potential antimicrobial agent in disinfecting root canals. A systematic Review. Int. J. Odontostomat., 10(3):547-554, 2016.

Synthesis and Characterization via Chemical Methods. Molecules., 17(12):14928-36, 2012.

Santo, C.E.; Lam, E.W. \& Elowsky, C.G. Bacterial killing by dry metallic copper surfaces. Appl. Environ. Microbiol., 77(3):794-802, 2011.

Semisch, A.; Ohle, J.; Witt, B. \& Hartwig, A. Cytotoxicity and genotoxicity of nano-and microparticulate copper oxide: role of solubility and intracellular bioavailability. Part. Fibre Toxicol., 11:10, 2014.

Sengupta, J.; Ghosh, S.; Datta, P.; Gomes, A. \& Gomes, A. Physiologically Important Metal Nanoparticles and Their Toxicity. J. Nanosc. Nanotechnol., 14(1):990-1006, 2014.

Shrestha, A. \& Kishen, A. Antibacterial efficacy of photosensitizer functionalized biopolymeric nanoparticles in the presence of tissue inhibitors in root canal. J. Endod., 40(4):566-70, 2014.

Sierra, M.; Sanhueza, A.; Alcántara, R. \& Sánchez, G. Antimicrobial evaluation of copper sulfate (II) on strains of Enterococcus faecalis. In vitro study. J. Oral Res., 2:114-18, 2013.

Thit, A.; Selck, H. \& Bjerregaard, H.F. Toxicity of CuO nanoparticles and $\mathrm{Cu}$ ions to tight epithelial cells from Xenopus laevis (A6): effects on proliferation, cell cycle progression and cell death. Toxicol. In Vitro., 27:15961601, 2013.

Usman, M.; Zowalaty, M.; Shameli, K.; Zainuddin, N. \& Salama, M. Synthesis, characterization, and antimicrobial properties of copper nanoparticles. Int. J. Nanomedicine., 8:4467-79, 2013.

Vargas-Reus, M.A.; Memarzadeh, K.; Huang, J.; Ren, G.G. \& Allaker, R.P. Antimicrobial activity of nanoparticulate metal oxides against peri-implantitis pathogens. Int. J. Antimicrob. Agents., 40(2):135-9, 2012.

Wang, Z.; Von Dem Bussche, A.; Kabadi, P.; Kane, A. \& Hurt, R. Biological and Environmental Transformations of Copper-Based Nanomaterials. ACS Nano., 7(10): 871527, 2013.

Warnes, S.L.; Highmore, C.J. \& Keevil, C.W. Horizontal transfer of antibiotic resistance genes on abiotic touch surfaces: implications for public health. MBio., 3(6):e00489-00412, 2013.

Yang, M.; He, J.; Hu, M.; Xiaochun, H.; Chunxiao, Y. \& Cheng, Z. Synthesis of copper oxide nanoparticles and their sensing property tohydrogen cyanide under varied humidity conditions. Sensor Actuat. B-Chem., 213:5964, 2015.
Yoon, K.Y.; Hoon J.; Park, J.H. \& Hwang, J. Susceptibility constants of Escherichia coli and Bacillus subtilis to silver and copper nanoparticles. Sci. Total Environ., 373:5725, 2007.

Zain, N.; Stapley, A. \& Shama, G. Green synthesis of silver and copper nanoparticles using ascorbic acidand chitosan for antimicrobial applications. Carbohydr. Polym., 112:195-202, 2014.

Correspondence to:

Gabriela Sánchez-Sanhueza

Departamento de Odontología Restauradora

Facultad de Odontología

Universidad de Concepción

Roosevelt \#1550

Fono: 56- 412204481

Concepción

CHILE

Email: gasanchez@udec.cl

Received:10-05-2016

Accepted:17-10-2016 